\title{
AN EXPERIMENT USING THE GRAPHIC VARIABLE COLOR AND THE SEE COLOR CODE ON ISARITHMIC MAPS ACCESSIBLE TO BLIND AND NORMALLY SIGHTED PEOPLE
}

\section{Um experimento usando a variável gráfica Cor e o código See Color em mapas isarítmicos acessíveis para pessoas cegas e com visão normal de cores}

Niédja Sodré de Araújo ${ }^{1}$ - ORCID: 0000-0002-9578-9600

Fabrício Rosa Amorim ${ }^{1}$ - ORCID: 0000-0002-6670-2131

Amanda Pereira Antunes ${ }^{1}$ - ORCID: 0000-0001-9458-1368

Sandra Regina Marchi ${ }^{2}$ ORCID: 0000-0002-1679-0823

Marcio Augusto Reolon Schmidt ${ }^{1}$ - ORCID: 0000-0003-2716-2360

Andrea Faria Andrade ${ }^{1}$ - ORCID: 0000-0002-5378-2451

Luciene Stamato Delazari ${ }^{1}$ - ORCID: 0000-0003-0018-085X

\footnotetext{
${ }^{1}$ Universidade Federal do Paraná, Programa de Pós-Graduação em Ciências Geodésicas, Curitiba-PR, Brasil. E-mails: niedja.geo@gmail.com; fabricioamorimeac@hotmail.com; amandapereiraantunes@gmail.com; marcio.schmidt@ufu.br; afariandrade@gmail.com; luciene@ufpr.br

${ }^{2}$ Universidade Federal do Paraná, Programa de Pós-graduação em Design, Curitiba-PR, Brasil. E-mail: marchi.sandra@gmail.com
}

Received in $8^{\text {th }}$ July 2020

Accepted in 29th November 2020

\begin{abstract}
:
The See Color is a color coding system based on Braille writing to communicate colors to people with visual impairments. This study assessed the perception of the theme Temperature by blind people, by using the See Color code on two isarithmic tactile maps and the perception of subjects with normal color vision. An average temperature map of Australia had 10 classes, but these intervals were regrouped into four classes on Corel Draw software. The new map was duplicated in the digital project in A4 size, both included the See Color code in two color schemes obtained from the Color Brewer website. Subsequently, they were laser-printed on swell paper to produce the tactile relief. The chromatic perception was observed, as well as the thermal sensations that the colors could represent for blind participants (06), normally sighted participants in basic education (23), and normally sighted participants in higher education (20). In this research, the See Color code showed the potential to provide spatial knowledge as a graphic language through colors in color maps for adventitiously blind and for normally sighted participants based on their perception of colors and tactile color codes.
\end{abstract}

Keywords: Color Code; Visual Impairment; Tactile Map; Perception; Symbology.

How to cite this article: ARAÚJO, N.S.; AMORIM, F.R.; ANTUNES, A.P.; MARCHI, S.R.; SCHMIDT, M.A.R.; ANDRADE, A.F.; DELAZARI, L.S. An experiment using the graphic variable color and the see color code on isarithmic maps accessible to blind and normally sighted people. Bulletin of Geodetic Sciences. 27(spe): e2021006, 2021. 


\section{Resumo:}

O See Color é um sistema de códigos de cores baseado na escrita em Braille para comunicar as cores para pessoas com deficiência visual. Este estudo avaliou a percepção do tema Temperatura por pessoas cegas, utilizando o código See Color em dois mapas táteis israítmicos e a percepção de pessoas com visão normal de cores. Um mapa de temperatura média da Austrália continha 10 classes, mas estes intervalos foram reagrupados em quatro classes no software Corel Draw. O novo mapa foi duplicado no projeto digital em tamanho A4 e incluíram-se os códigos See Color em dois esquemas de cores obtidos no website Color Brewer. Em seguida, os mapas foram impressos a laser sobre papel microcapsulado para produção do relevo tátil. A percepção cromática foi observada, assim como as sensações térmicas que as cores poderiam representar para os participantes cegos (06), para os participantes normovisuais do ensino básico (23) e do ensino superior (20). Nesta pesquisa, os mapas mostraram potencial para fornecer conhecimento espacial para participantes cegos adquiridos e normovisuais com base na percepção de cores e códigos de cores táteis usados como linguagem gráfica.

Palavras-chave: Código de Cor; Deficiência Visual; Mapa Tátil; Percepção; Simbologia.

\section{Introduction}

The Brazilian Ophthalmology Council (2019) defines blindness as a vision impairment that makes the people's routine tasks impractical, even if they have certain degrees of residual vision, and total blindness as the complete loss of vision, including the inability to perceive light. Partially blind people may perceive shapes and light, or count fingers at close range, in other words, they have restricted visual field and accuracy. Congenitally blind people are those who lost their vision before the age of five (Nunes and Lomônaco, 2008). More than $82 \%$ of all blind people in the world are above 50 years old and over $90 \%$ of the cases of visual impairment occur in developing countries, such as Brazil, mainly impacting socioeconomically vulnerable people. Although $40 \%$ of the causes of childhood blindness are preventable or treatable, 500,000 children worldwide are blinded annually, almost one per minute, due to measles, meningitis, rubella, genetic diseases, among others (Conselho Brasileiro de Oftalmologia, 2019).

The creation of products with assistive technology is incredibly important in the inclusion of visually impaired people around the globe. Assistive technology consists "of products, equipment, devices, resources, methodologies, strategies, practices, and services that promote functionality related to the activity and participation of people with disabilities or reduced mobility, aiming at their autonomy, independence, quality of life and social inclusion" Brasil, 2015. In this context, tactile maps can be considered as assistive technology resources in education, as a means for teaching Geography, or in architectural projects for accessibility, guidance and indoor or outdoor mobility, supporting visually impaired users to reach conclusions and spatial decisions.

According to the Statute for People with Disabilities, the principle of Universal Design should be applied in order to "design products, environments, programs, and services to be used by all people, without the need for adaptation or specific projects, including assistive technology resources" Brasil, 2015. The most common production techniques in the area of tactile cartography are: thermoforming, supported by the principle of shaping maps by applying vacuum pressure under plastic material; thermal printing on swell paper, supported by the principle of shaping the map from the expansion of microcapsules of alcohol, using a heat fusing machine; embossing; manual techniques; 3D printing, which has been widely used in the last 20 years; and also interactive maps produced for computer interfaces and other accessible devices (Koch, 2012).

According to Koch (2012), agreeing symbols and their uses on tactile maps is a challenging task due to the different production methods, restriction on the number of symbols easily discriminable by touch, and individual singularities in tactile perception. Based on the Statute of the Person with Disabilities, in order to comply with the principle of Universal Design, maps should be accessible to blind, color-blind, low-vision and normally sighted people. According to Pugliesi 
and Decanini (2011), color-blind people have disabilities in the color-sensing cones in their eyes. Therefore, in daily life and during the use of maps, they have a different visual perception than those with normal color vision.

Bianchi, Ramos and Barbosa-Lima (2016) carried out a research on the meaning of colors for congenitally blind and normally sighted participants. It was found that it is similarly abstracted by both groups, as blind people also share the same visual culture. In Brazil, the See Color code was approved by the Benjamin Constant Institute to teach the concept of colors to people with visual impairments through tactile color codes (seecolor.com.br). Exploratory studies on the use of the See Color code were developed by Ribeiro (2019) using a work of art and by Araújo et al. (2020) using tactile temperature maps.

Currently, only sound resources can communicate colors on maps to blind people. In the literature colors are considered accessible only to those able to see. Thus, this research begins with the following question: how could blind people or normal color vision people understand geographical phenomena through colored tactile maps? Thus, in this study we assume that the See Color system can be adequate in the use of colored tactile maps to provide equity in the process of acquisition of spatial knowledge. In this context, in this research we evaluate the interpretation of congenital blind, acquired blind and normovisual people about the theme average temperature on maps using the color graphical variable and See Color codes in relief.

\section{Graphic variables on tactile maps and the See Color code}

In the tactile cartography, the systematization of tactile graphic variables (Figure 1) proposed by Vasconcellos (1993) stands out. It was designed from the adaptation of visual graphic variables created by Jacques Bertin in 1977 . Since then, the color has remained an exception among the variables for being considered restricted to people who are able to see.

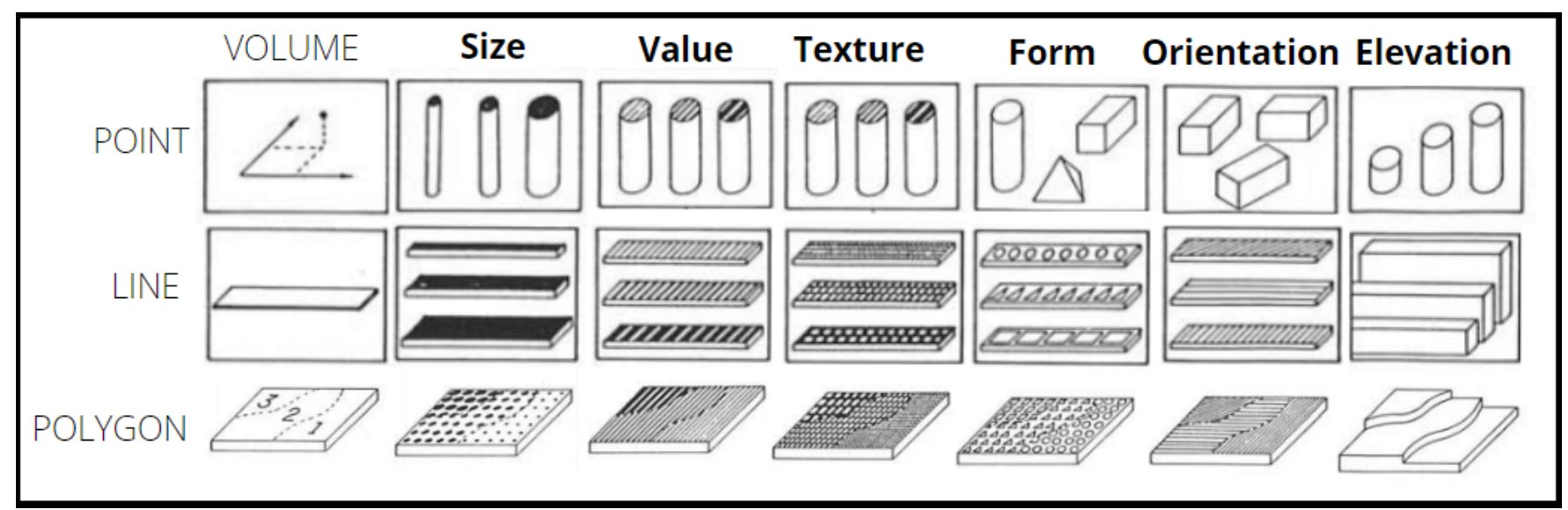

Figure 1: Tactile Graphic Variables. Source: Adapted from Vasconcellos (1993).

According to Nogueira (2008), people with normal vision are able to easily differentiate the graphic variable Texture on maps due to their simultaneous perception of the map as a whole. However, visually impaired people have more difficulty in distinguishing these variables. Therefore, it is recommended using a maximum of 7 types of variables. The author also states that the smaller the scale of the map, the more complex the tactile discrimination of graphic variables implemented in each area will be, and the more difficult it will be to use textures. It has been found that visually impaired people can discriminate classes or attributes on tactile maps more easily through letters than through textures. Maps made with the graphic variable Color are accessible only to people with normal or low vision, as long as contrasting colors are used (Nogueira, 2008). 
Although it is possible to develop accessible maps for blind and low-vision users, it is a complex challenge due to the different degrees of visual accuracy or vision span of those with low vision. However, tactile maps can be an alternative for most people with visual impairments (Nogueira, 2008). Similarly, to the use of letters to represent zonal phenomena on tactile maps, the See Color code can communicate colors to people with visual impairments. According to Oliveira (1998), the adventitiously blind can keep visual memories of images, lights and colors depending on the age at which they lost their sight, while the blind who have never had any visual experience will consider colors an abstraction. In this context, it is estimated that by using the See Color code on maps, it is possible to consider the existence of visual memory in the adventitiously blind, the ability of abstraction of the congenitally blind, and the ability of people with low vision to distinguish colors, even if not contrasting, through embossed color codes.

According to Dent, Torguson and Hodler (2009), the selection of colors is one of the most interesting options for the cartographer when designing thematic maps. According to Pedrosa (2010), primary colors are three hues that, combined with each other, originate any other color in the visible spectrum. The primary additive colors are red (R), green (G), and blue (B), which make up the RBG system. They originate the color white by additive synthesis, as well as the secondary colors magenta $(\mathrm{M})$, yellow $(\mathrm{Y})$ and cyan $(\mathrm{C})$, which form the subtractive CMYK system. On the other hand, in pigment theory the primary colors are red $(R)$, yellow $(Y)$, and blue (B), the RYB system. These colors combined produce an almost black gray. The primary pigment colors when combined in pairs create the secondary colors orange, green, and purple, which combined with any other color form tertiary colors, completing the chromatic circle.

According to Silveira (2011), different people perceive colors similarly, but there are subtle differences that must be considered when designing visual products. This author states that chromatic sensation is the moment when the light existing on something reaches the eyes and causes the physiological codification of that determined luminous flux. Chromatic perception is the culturally established interpretation of that coding, that is, it originates from the communication between human beings. The symbolic cultural aspects of chromatic perception are important in project development since the effectiveness of the symbolic representation of the visual world depends on the cultural process of understanding colors. According to Pedrosa (2010), chromatic perception is more complex than chromatic sensation, as the first depends on psychological aspects of what is seen and can be distinguished by three basic color parameters: hue (wavelength), value (brightness), and chroma (saturation or color purity). The colors scheme or the relationship between them can cause a visual sensation of hot or cold colors, so the red, yellow and their derivatives can be considered hot, but their complementary colors can be considered cold (Pedrosa, 2010).

The See Color code system (Figure 2) designed by Sandra Marchi was inspired by Braille writing and the Chromatic Triangle, developed to teach color theory to people with visual impairments, who also share the same visual culture (Marchi, 2019), even having no experience of the physiological codification of luminous fluxes by the sense of sight. The See Color code was designed analogous to a clock, containing the primary colors at its markings: red (12 o'clock), yellow (4 o'clock), and blue ( 8 o'clock). The secondary colors were positioned between them: orange (2 o'clock), green (6 o'clock) and purple or lilac (10 o'clock). Each tactile symbol of the See Color code has a fixed center point of origin "." and a dash "|"called Directed Line, which is similar to the hour hand on a clock. It characterizes the hue of the color, analogously to a chromatic hexagon. Darker hues have an additional point to the left of the center point, and lighter hues have an additional point to the right of the center point. Below the central point is a fixed horizontal line "_" that is a reference element to guide the user on the correct position of the code. 


\begin{tabular}{|c|c|c|c|c|c|c|c|c|}
\hline 1 & $\begin{array}{l}\text { ee } \\
\text { Color } \\
\because \because\end{array}$ & de S & $\frac{\mathrm{Or}}{\mathrm{em}}$ & $\begin{array}{r}\text { - Directed } \\
\text { - orientat } \\
\text { Referen } \\
\text { - correct }\end{array}$ & $\begin{array}{l}\text { le relate } \\
\text { ); Has a } \\
\text { ine (fixe } \\
\text { e positi }\end{array}$ & $\begin{array}{l}\text { d to th } \\
\text { fixed c } \\
\text { d); Info } \\
\text { on. }\end{array}$ & $\begin{array}{l}\text { color } n \\
\text { ter po } \\
\text { ms the }\end{array}$ & $\begin{array}{l}\text { e (variable } \\
\text { er on the }\end{array}$ \\
\hline See Color Chror & c Guide & Dark & Light & See Color Chron & ic Guide & Dark & Light & Chromatic hexagon \\
\hline Red & $\begin{array}{l}! \\
-\end{array}$ & $\begin{array}{l}1 ! \\
-\end{array}$ & $\begin{array}{l}\text { !. } \\
-\end{array}$ & Green & i & $\ddot{i}$ & $\ddot{i}$ & 2 \\
\hline Blue & '- & $\ddot{-}$ & $\stackrel{\cdots}{-}$ & Orange & $\begin{array}{l}\dot{0}^{\prime} \\
-\end{array}$ & $\begin{array}{l}.^{\prime} \\
-\end{array}$ & $\begin{array}{l}\because \\
-\end{array}$ & \\
\hline Yellow & $\because$ & $\because$ & $\because$ & Black & $\overrightarrow{-}$ & & & \\
\hline Lilac & $\begin{array}{l}\ddots \\
-\end{array}$ & $\begin{array}{l}2 . \\
-\end{array}$ & $\begin{array}{l}\ddots \\
-\end{array}$ & White & $\begin{array}{l}\cdot-\cdot \\
-\end{array}$ & & & \\
\hline
\end{tabular}

Figure 2: See Color code system related to the chromatic hexagon. Source: Marchi (2019) apud Araújo et al. (2020).

Araújo et al. (2020) found that in the last 10 years, color coding systems have not yet been tested within regions on thematic tactile maps for users with blindness or low vision. A study on the use of color codes in maps for mobility and orientation of both color-blind and normally sighted people in the subway (Figure 3 ) in the city of Porto in Portugal was found in the literature, combining the graphic variable Color and ColorADD system codes (http://www.coloradd.net/code.asp). This system was created in 2008 by the Portuguese researcher Miguel Neiva, using the graphic variables Shape and Orientation for 25 color codes, including variations of hue, saturation, and luminosity (Neiva, 2016).

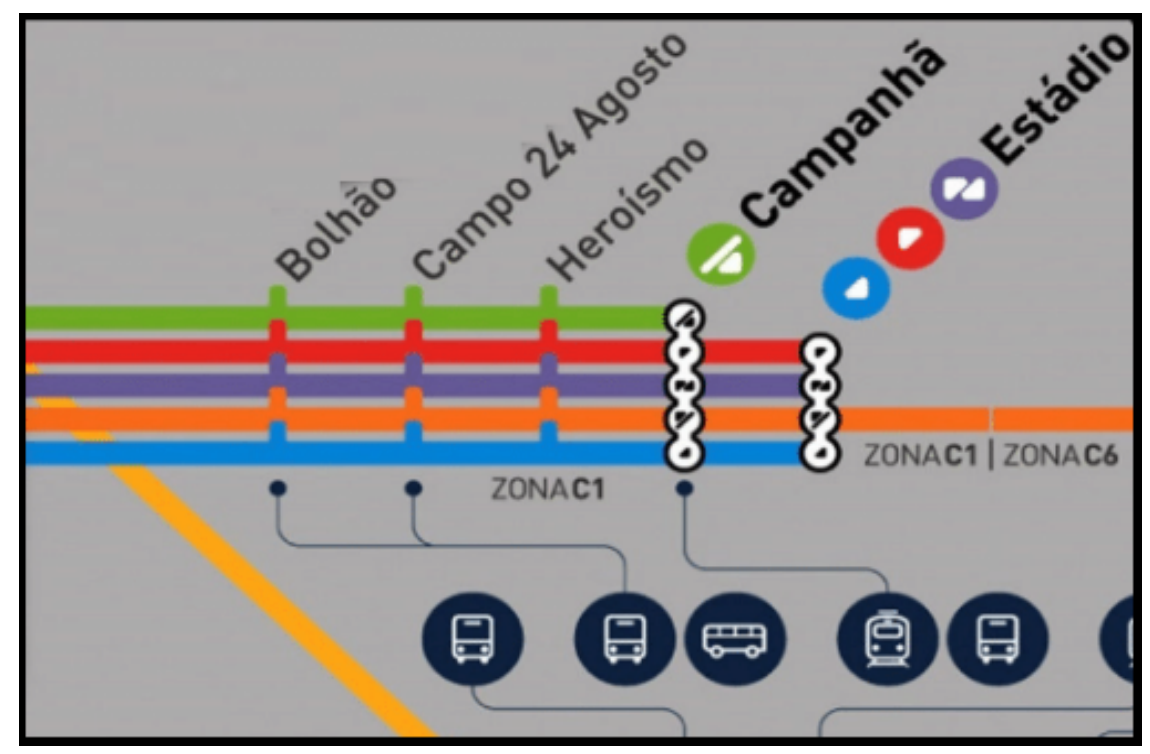

Figure 3: Partial map of the Porto metro in Portugal. Source: Adapted from Neiva (2016). 


\section{Methodology}

\subsection{Cartographic design and See Color code learning}

According to Koch (2012), the literature recommends that tactile maps have a size of approximately $30 \mathrm{~cm}$ $x 40 \mathrm{~cm}$, so that the notion of the whole is reached by the touch of the hands of adult users. The number of different symbols used on a tactile map is on average between 10 and 15, including up to 6 types of points, 4 types of lines, 4 areas, and using saturated and contrasting colors in order to make it accessible by users with low vision (Rowell and Ungar apud Koch, 2012). Thus, when designing the cartographic design of a thematic map, the graphic variables to be used in the communication of the specific theme for a particular group of users must be selected considering their capabilities. According to Dent, Torguson and Hodler (2009), isarithmic maps that contain isolines connecting points or locations of equal value can present continuous 3D volumes such as altitude, temperature, or precipitation, and correspond to one of the quantitative mapping techniques. These authors suggest that for each project purpose a specific technique associated with visual graphic variables is used in a graphic system formed by points, lines, or areas to indicate the spatial phenomenon. However, on tactile maps this graphic system needs to be understood by tactile perception, by means of an embossed cartographic language (Almeida, 2011). In this context, the present research used a cartographic design elaborated in a previous study (Araújo et al., 2020) depicting the territory of Australia as the study area, as it presents hot and cold regions, and is not located in the Americas, thus avoiding previous participant conclusions about climatic characteristics. For this project, an image of an average temperature map of Australia (Figure 4) was downloaded from the Maps of World website (mapsofworld.com) in an approximate scale of 1:28,200,000.

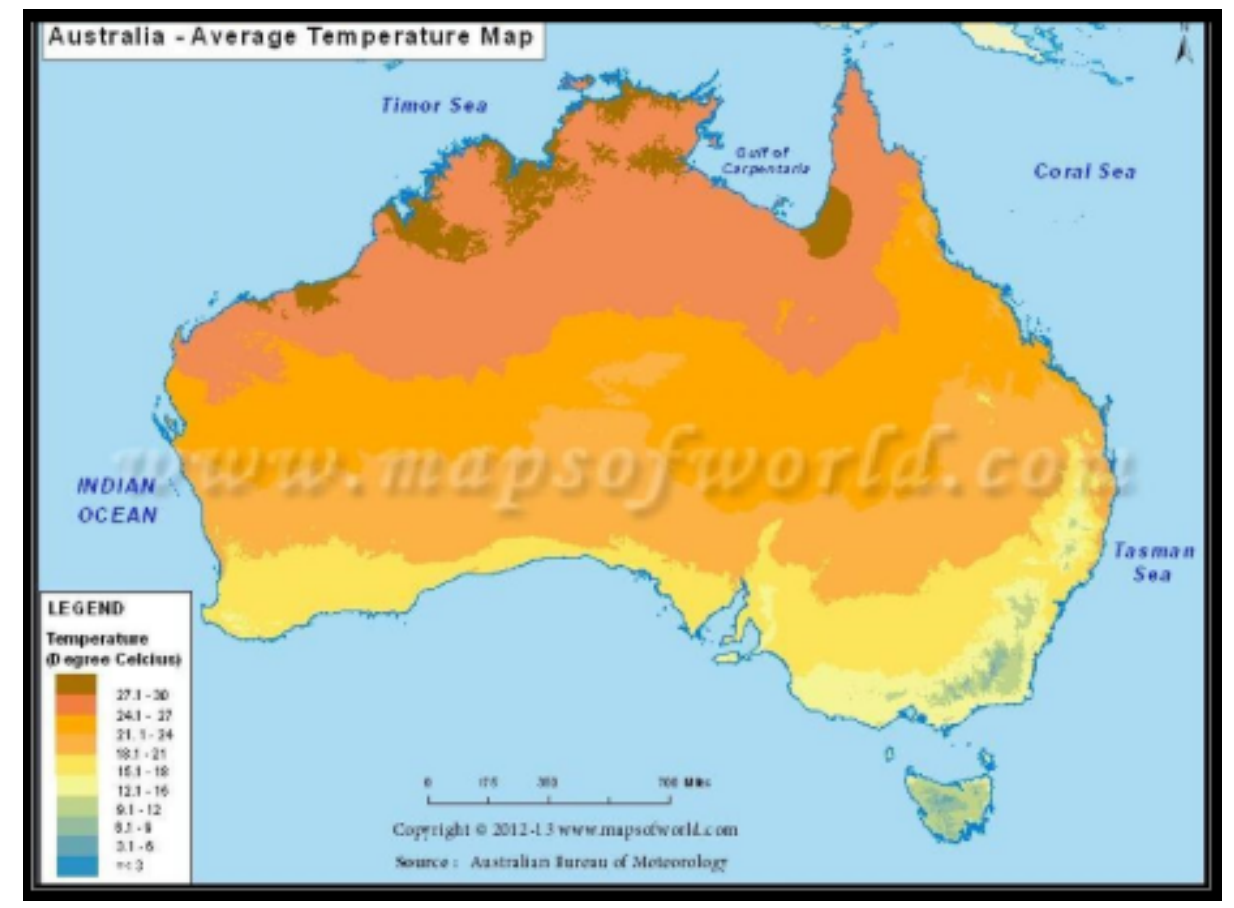

Figure 4: Average Temperature Map of Australia. Source: Maps of World (2012).

The theme Average Temperature was selected for being related to the users' sensory perception, for integrating the climate content taught in basic education, and also for its ordinal character, which allowed it to be represented cartographically by means of the variable Color Luminosity (Ministry of Education, 2017). However, the map was not 
georeferenced for accurate scale maintenance because the user's perception of the spatial dimension would not be assessed in the test. The image was vectorized on Corel Draw software in A4 size for accommodating the two maps produced ( $A$ and $B$ ), which were compatible with the guidelines of the cartographic design , with the original scale, and with the capacity of the heat fusing machine used in the production of the map, resulting in dimensions of $13.7 \mathrm{~cm}$ East-West by $11.6 \mathrm{~cm}$ North-South. The edge thickness of the areas and margins of the maps measured $1.0 \mathrm{~mm}$ based on previous studies (Jehoel, 2007; Bem, 2016). Braille titles for the blind and Roman-lettered titles for participants with normal vision were added. The archipelagos of Australia were aggregated on the map during the vectorization of the features of interest in order to enable the implantation of tactile symbols. Originally, the map had 10 classes ranging from $3^{\circ} \mathrm{C}$ to $30^{\circ} \mathrm{C}$, which were regrouped into four regions with the following intervals: $3^{\circ} \mathrm{C}$ to $15^{\circ} \mathrm{C}, 15.1^{\circ} \mathrm{C}$ to $21^{\circ} \mathrm{C}, 21.1^{\circ} \mathrm{C}$ to $24^{\circ} \mathrm{C}$, and $24.1^{\circ} \mathrm{C}$ to $30^{\circ} \mathrm{C}$. By doing so, it was possible to homogenize similar temperatures so that the codes could be recognized by touch within each area. These codes were positioned as close as possible to the center of each area and distance greater than $2.3 \mathrm{~mm}$ from the edges, as recommended in a previous study on the development of tactile symbols (Araújo, Fernandes and Alixandrini Jr., 2019) for example, $6 \mathrm{~mm}$ between the symbol and other tactile element (Bernardi, 2007). The project was laser-printed in color on swell paper, which was then submitted to a heat fusing machine to produce the tactile relief. The CMYK (cyan, magenta, yellow, black) system was used for color printing on both schemes obtained from the Color Brewer website (colorbrewer2. org), which is a web tool that recommends adequate color schemes for the production of thematic maps. On the first map, titled TEMPERATURE MAP A, a scheme for diverging data was used, that is, hues that are considered opposite in color theory (Pedrosa 2010). Shades of blue stand for low temperatures, while shades of red and orange stand for high temperatures. On the second map, titled TEMPERATURE MAP B, a multi-hue scheme was used for data of a sequential nature, that is, different but analogous in color theory (Pedrosa, 2010). The color yellow represents low temperatures while the colors red and orange represent high temperatures, as shown in Figure 5.

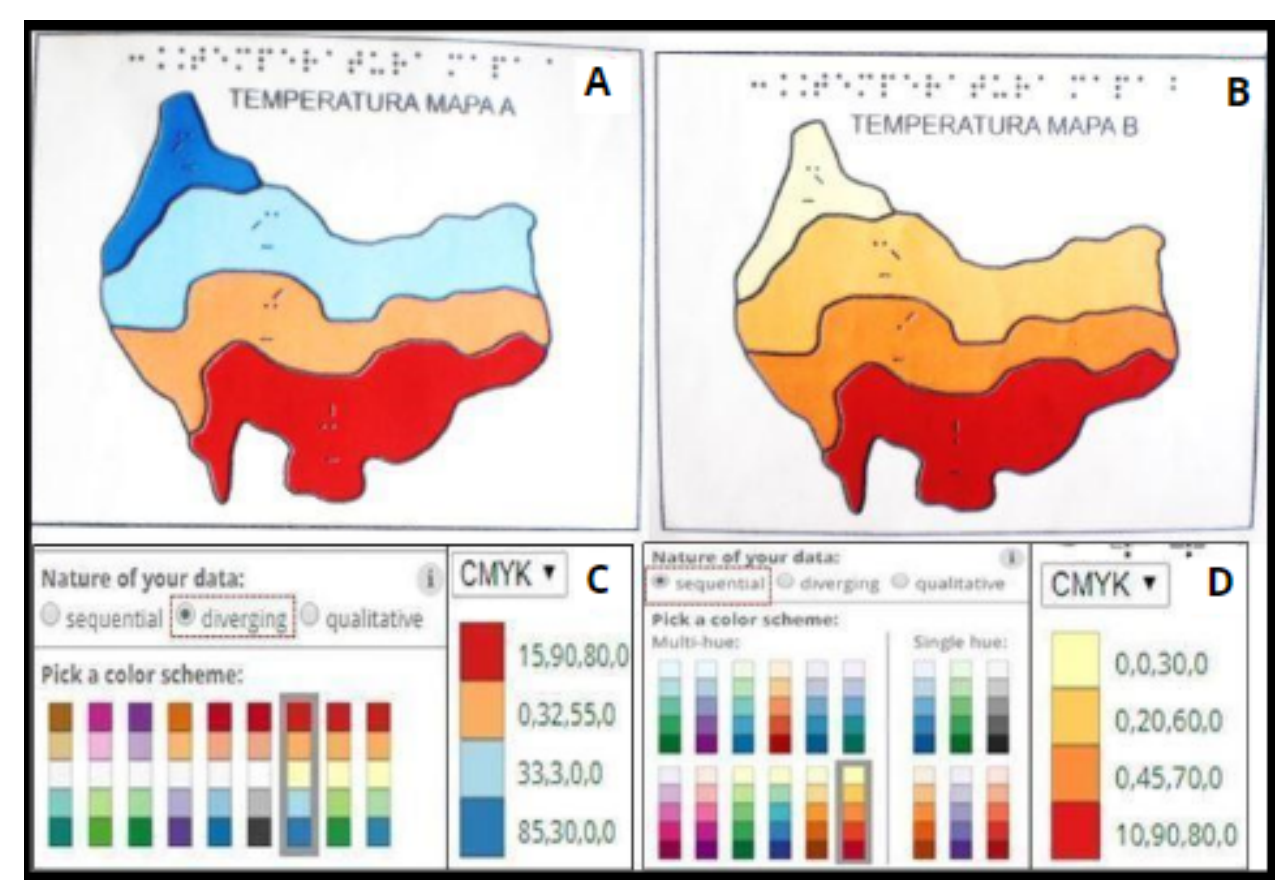

Figure 5: Tactile maps ( - Temperature Map A; B - Temperature Map B; C - Color scheme used on Map A; D Color scheme used on Map B). Source: Araújo et al. (2020).

The temperature data were considered sequential and diverging, as they were ordered by intervals below $15^{\circ}$ with amplitude of up to $30^{\circ} \mathrm{C}$, and thus composed of divergent regions, either hot or cold. Finally, the See Color codes corresponding to the following hues were selected: dark blue, light blue, light orange, and dark red, which 
respectively represented the classes $3^{\circ} \mathrm{C}$ to $15^{\circ} \mathrm{C}, 15.1^{\circ} \mathrm{C}$ to $21^{\circ} \mathrm{C}, 21.1^{\circ} \mathrm{C}$ to $24^{\circ} \mathrm{C}$, and $24.1^{\circ} \mathrm{C}$ to $30^{\circ} \mathrm{C}$ on $\mathrm{Map} \mathrm{A}$. Similarly, light yellow, dark yellow, orange, and red represented the same intervals on Map $\mathrm{B}$. The legends of the maps were omitted to check if the colors would have a representative meaning for blind people in the interpretation of the maps. Otherwise, the users' answers about the color's thermal sensation could be associated with the numerical values informed in the legend and not with the subjectivity of the color meaning. The orientation from north to south was reversed to avoid possible relations with the conventional shape of the map of Australia. The orientation of the study area was omitted to avoid any correlation with the Brazilian climatic characteristics (Araújo et al. 2020).

\subsection{Characterization of Users and Tasks Using the Maps}

Before the maps were analyzed, the hexagon of the See Color code system was explained to users individually with the aid of an appropriate pedagogical kit containing the color codes in acrylic resin for memorization. The time for learning See Color and completing tasks with the maps was recorded together and totaled an average of 38 minutes per blind person. About users with normal color vision, the time for tasks was not recorded, as it was not essential for research. The tactile material adopted in tasks with the blind users integrates two models of color maps: one with a divergent scheme and another with a sequential scheme printed on swell paper with tactile relief; a See Color kit (Figure 6) consisting of two wooden triangles with acrylic circles at the ends with a specific color code in relief; a computer with internet to researcher fill out a spreadsheet in google forms containing the fields to save the answers of blind users about the tasks with the maps or for the participants with normal color vision to save their own answers.

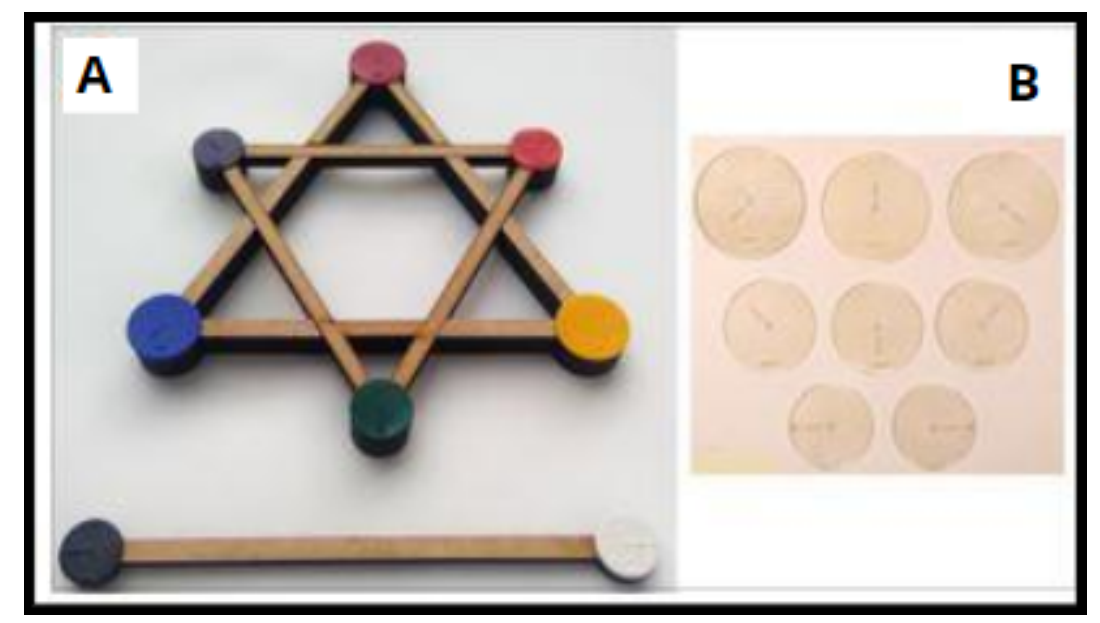

Figure 6: See Color pedagogical kit (A - Chromatic triangles with colored acrylic resin; B - Acrylic resin plates with the See Color code). Source: Marchi (2019).

The See Color code was explained individually to each of the six blind participants. First, the concept of primary colors was presented, Thus, a meeting took place with each participant at the Institute for the Blind People of Bahia (ICB). These colors were depicted on the wooden triangle with the color codes Red at the top, Yellow at bottom right, and Blue at bottom left. All codes were embossed on acrylic material. Then, the concept of secondary colors was explained with the aid of a second wooden triangle, positioned inversely over the first, with the color code Green at the bottom, Orange at top right, and Purple ( $\mathrm{lilac}$ ) at top left. Participants were told that secondary colors originate from the mixing of primary ones, that is, in color theory orange is formed from mixing red and yellow, green is formed from mixing yellow and blue, and purple is formed from mixing blue and red. To consolidate the learning process, all 
resin plates containing the codes for primary and secondary colors were randomly handed to the users, one at a time, so that they could name the represented color. The process was repeated until all answers were correct. Lastly, the representation of the tertiary color codes was explained to the participants as follows: if the shade of a given color is light, its code will have an additional point on the right side of the center point, but if the shade of a color is dark, its code will have an additional point on the left side of the center point. However, acrylic plates only contained examples of primary and secondary color codes, so the explanation of tertiary codes was only theoretical.

In map usability tests, it is common to use the principle of minimal sample size proposed by Nielsen and Landauer (1993). These authors recommend a minimum number of participants of five subjects. Kitchin and Jacobson (1997) acknowledge the difficulty in deciding the number of visually impaired subjects to be recruited to participate in research with tasks, interviews or questionnaires, but stress that every effort must be made to reach significant sample sizes in order to obtain reliable generalizations about the knowledge and ability of visually impaired people to perform spatial analysis. The research carried out by Araújo et al. (2020) was a preliminary study on the potential of the See Color code for use on tactile maps based on the perception of blind participants, since at the time only six blind people at the Institute for the Blind People of Bahia in 2019 agreed to participate in the research. The sample of blind subjects consisted of four high school students aged between 18 and 21 years (three female and one male), and two female post-graduate teachers aged over 40 years. Three of them were congenitally blind and three were adventitiously blind (with visual memory). Among the adventitiously blind subjects there was one student who lost her sight at six years old and one teacher who developed blindness between 13 and 18 years old. All blind subjects had already had previous experience using maps at the ICB. In order to participate in the study, it was necessary that the blind subject had attended at least elementary school, due to the importance of having knowledge about the climate for analyzing average temperature on the thematic maps. The analyses considered the types of blindness of each subject. The tasks were performed during a workshop at the ICB after a lecture given by one of the researchers, under the authorization of the ICB board and with the acceptance of the participants. The sample of subjects with normal vision included 20 undergraduate students from the cartographic engineering course of the University Federal of Paraná in Brazil, of which 9 were female and 11 were male, aged between 20 and 30 years. All subjects had previous experience in using thematic maps. The tasks regarding the participant's perception of colors were performed with their acceptance during the teaching internship of one of the researchers in the present study, who taught thematic cartography. The sample of normally sighted subjects also included 23 basic education students from Papa João Paulo I State School, located in the countryside of the State of Bahia (Brotas de Macaúbas), in Brazil. Eleven students were female and 12 were male, all were aged between 15 and 20 years and had previous experience in using maps.

For this study, three groups were defined for data analysis: blind participants (congenitally and adventitiously blind), normally sighted participants in higher education (undergraduate), and normally sighted participants in basic education (02 in elementary school and 21 in high school). Regarding the tests with the participation of blind people, the methodological procedures of this research were based on the "Think Aloud" method, which considers the users' responses during spatial analysis tasks using maps. Thus, we consider the memorization of See Color, the perception of color association with thermal sensation and See Color cognition in tactile maps. In relation to tests with people with normal color vision, the perception of the color variable associated with the thermal sensation was mainly evaluated, as well as the cognition related to the name of the color, using the same method. According to Šterrba et al. (2015), the think-aloud method allows the researcher to evaluate the effectiveness of the product and the satisfaction of users through tasks related to its usability, as it takes into account the user's cognitive processes immediately or shortly after using the maps. Other techniques might be quite limited, such as surveys that explore user orientation. The proposed qualitative tasks aimed to investigate the users' cognitive processes when using the maps in order to obtain the number of right and wrong answers through the think-aloud method. The answers were saved in a questionnaire on Google Forms by one of the researchers and in an electronic spreadsheet. The statistical method of averaging was used for quantitative analysis of responses of each group of users. The tasks regarding color perception or interpretation of color codes for blind and normally sighted participants were: 
1) Name the color of the $1^{\text {st }}$ region;

2) Name the color of the $2^{\text {nd }}$ region;

3) Name the color of the $3^{\text {rd }}$ region;

4) Name the color of the $4^{\text {th }}$ region;

5) Inform the thermal sensation related to the color on the map (the map contains only hot regions; the map contains only cold regions; the map contains hot and cold regions; that cannot be inferred based on the colors).

\section{Results and Analysis}

The answers on the assessment of the color schemes of Map A and Map B were organized in Tables 1, 2, and 3 , containing the number of answers expected of each group of users. Blind participants were categorized according to their type of blindness, that is, congenitally blind (CB) or adventitiously blind (AB). Normally sighted participants were categorized according to their education level, that is, basic or higher education.

Table 1: Analysis of the See Color code on tactile temperature maps by blind users.

\begin{tabular}{ccc}
\hline Topics analyzed & Expected Answers: Map A & Expected Answers: Map B \\
\hline Number of Regions & 06 blind users = 04 regions & 06 blind users = 04 regions \\
\hline 1st Region Color & $02 \mathrm{CB}$ and $03 \mathrm{AB}=$ Dark Blue & $03 \mathrm{CB}$ and 01 $\mathrm{AB}=$ Light Yellow \\
\hline 2nd Region Color & $03 \mathrm{CB}$ and $01 \mathrm{AB}=$ Light Blue & $03 \mathrm{CB}$ and $01 \mathrm{AB}=$ Dark Yellow \\
\hline 3rd Region Color & $01 \mathrm{CB}=$ Light Orange & $03 \mathrm{CB}$ and $02 \mathrm{AB}=$ Orange \\
\hline 4th Region Color & $02 \mathrm{CB}$ and $03 \mathrm{AB}=$ Dark Red & $03 \mathrm{CB}$ and $02 \mathrm{AB}=$ Red \\
\hline Thermal sensation related to the color & $01 \mathrm{CB}$ and $03 \mathrm{AB}=$ Hot and Cold & $01 \mathrm{CB}$ and $02 \mathrm{AB}=$ Hot and Cold \\
\hline & $*$ Adapted from Araújo et al. (2020). &
\end{tabular}

Table 2: Analysis of the See Color code on tactile temperature maps by normally sighted users in higher education.

\begin{tabular}{ccc}
\hline Topics analyzed & Expected Answers: Map A & Expected Answers: Map B \\
\hline Number of Regions & $20=04$ regions & $20=04$ regions \\
\hline 1st Region Color & $11=$ Dark Blue & $18=$ Light Yellow \\
\hline 2nd Region Color & $18=$ Light Blue & $08=$ Dark Yellow \\
\hline 3rd Region Color & $14=$ Light Orange & $14=$ Orange \\
\hline 4th Region Color & $04=$ Dark Red & $16=$ Red \\
\hline Thermal sensation related to the color & $20=$ Hot and Cold & $02=$ Hot and Cold \\
\hline & $*$ The authors. &
\end{tabular}


Table 3: Analysis of the See Color code on tactile temperature maps by normally sighted users in basic education

\begin{tabular}{ccc}
\hline Topics analyzed & Expected Answers: Map A & Expected Answers: Map B \\
\hline Number of Regions & $23=04$ regions & $23=04$ regions \\
\hline 1st Region Color & $16=$ Dark Blue & $14=$ Light Yellow \\
\hline 2nd Region Color & 20 Light Blue & $04=$ Dark Yellow \\
\hline 3rd Region Color & $15=$ Light Orange & $06=$ Orange \\
\hline 4th Region Color & $11=$ Dark Red & $07=$ Red \\
\hline Thermal sensation related to the color & $21=$ Hot and Cold & $08=$ Hot and Cold \\
\hline & $*$ The authors. &
\end{tabular}

For both types of blindness, the perception of colors through the reading of the color codes in the diverging scheme of Map A resulted in 19 equal responses for the same codes, whereas the reading of the color codes on Map B, which was created in a sequential scheme, resulted in 21 equal responses. The amount of correct answers on Map B was greater than on Map A because in the sequential scheme there was one primary color code (red) and a secondary color code (orange), which are less complex than tertiary color codes. The correct answers regarding Map B may also be related to the first experience users had just had with Map A, which improved their perception for the second test. As for the thermal sensation related to the colors, four participants correctly informed that there were hot and cold regions on Map A. Most of them (03) were adventitiously blind. Two congenitally blind participants said that nothing could be inferred based on the colors. Regarding Map B, two participants correctly informed that there were hot and cold regions. Two reported that there were only hot regions, and two congenitally blind participants said that nothing could be inferred.

Even though there were only two correct answers regarding thermal sensation on Map B, four participants agreed on the existence of hot regions. Of these four, three were adventitiously blind. Thus, considering the perception of blind users, the sequential color scheme used in this study would be recommended only for ordering regions with high temperatures. The diverging scheme could be indicated for both high and low temperatures, however, the thermal sensation indicated could make sense only for adventitiously blind users.

The following answers were expected regarding the tertiary colors of Maps A and B: light yellow, dark yellow, dark red, dark blue, light blue and light orange. The answers reported by blind participants regarding their chromatic perceptions of these color codes were $64 \%$ equal (23). In what concerns to the primary color red and for the secondary color orange, the expected answers were provided by a total of $83 \%$ of blind participants (10).

In this experiment it was possible to conclude that the adventitiously blind and the congenital blind were assertive in the recognition of color through See Color, however the adventitiously blind showed more interest in colors on maps than the congenital blind. Regarding cognition, all blind people reported that light or dark colors are difficult to recognize by touch because more attention is needed to the additional point to the left or right of the central point and the relief of the swell paper was less prominent than the acrylic material from the See Color kit.

At the end of the tasks, one of the congenital blind people commented that it was difficult to associate colors with a thermal sensation because she never saw the colors. At the time, the researcher asked the participant if she knew the color of the sun and the color of the sea and she answered yellow and blue, respectively. Then, the researcher asked if she knew the feeling of sunbathing and sea bathing, and if so, which of the situations would be warming or cooling. Then the participant answered that the sun warms, that the sea cools and concluded: "if you had given these examples before the tasks, it would be easier for me. I would have replied that yellow represents hot thermal sensation and blue cold thermal sensation". Thus, new interventions can be applied in future experiments to investigate how blind users could relate colors to spatial phenomena from perception of themselves and later propose spatial analysis tasks with color codes on tactile maps to evaluate the effectiveness of See Color as a graphic language in the process of acquisition of spatial knowledge. 
The group of normally sighted participants in higher education, three of the four colors on Map A were named correctly by $72 \%$. Dark blue (11), light blue (18), and light orange (14) were interpreted in accordance with the See Color code. The exception was dark red (4), which was referred to by most participants as red (12). All participants agreed that Map A contained hot and cold regions, what corroborates with the recommendation of using divergent color schemes to represent large thermal amplitudes. On Map B, all colors were interpreted correctly. Only $10 \%$ of participants (2) inferred that there were hot and cold regions on the map. The sequential scheme used is most suitable for hot regions. On the colors of Map B, 18 participants answered the first region was light yellow, eight answered the second region was dark yellow, 14 answered the third region was orange, and 16 answered the fourth region was red.

Regarding the answers of the group of normally sighted users in basic education, three of the four colors on Map A were named correctly by $77.5 \%$ of participants: dark blue (16), light blue (20), light orange (15), and dark red (11). Almost all participants (21) agreed that Map A contained hot and cold regions. As for Map B, 35\% of participants (08) inferred that there were no hot and cold regions, and 65\% (15) concluded that there were only hot regions.

It was found that the chromatic perception of participants in basic education was similar and more compatible with the meaning of the color codes. It was noted that for this group of users, the sequential color scheme of Map B was more appropriate for hot regions with low thermal amplitude. Regarding the colors of this map, 14 users answered that the first region was light yellow, 04 defined the second region as dark yellow, 06 defined the third region as orange, and 07 answered that the fourth region was red.

The answers reported by normally sighted people in higher education had $61 \%$ equality, and answers by normally sighted people in basic education had $58 \%$ equality (80). Both visual and tactile perceptions about tertiary colors and color codes were similar for all users in this experiment. In what concerns to the primary color red and for the secondary color orange, the expected answers were provided by a total of $75 \%$ of normally sighted participants in higher education (30), and only $28 \%$ of normally sighted participants in basic education (13).

However, the discrepancy of the answers given by normally sighted participants in basic education in relation to those given by other participants may be due to the lighting in the rooms where the experiment was carried out. Participants in higher education analyzed the colored maps under natural lighting at the beginning of the afternoon, while participants in basic education analyzed the maps under artificial lighting during the night and interpreted the color of the fourth region of Map B as dark red instead of red (11), and the color of the third region as dark orange instead of orange (11).

\section{CONCLUSION}

In this study, the qualitative analysis of the participants' chromatic perception was observed, as well as the thermal sensations that the colors could represent for blind participants, normally sighted participants in basic education and normally sighted participants in higher education. Adventitiously blind participants associated sequential colors of map B with hot thermal sensation and the divergent scheme of map A with hot and cold thermal sensations. However, this relationship may not occur among congenitally blind people due to the lack of visual color memory. All blind people memorize the color codes, but a suggestion for future studies would be interesting to perform the same tasks after a week to verify that the system's learning has been consolidated. To evaluate the usability of See Color in tactile maps, we recommend including the map legend and increasing the participation of blind users to obtain more significant generalizations. In this context, the time for learning See Color and conclusion of the tasks should be timed recorded separately to support future analysis of map efficiency. About the relation to colored maps for the blind, their material should be the same as the material used in memorizing See Color to ensure equality in tactile cognition during tasks, because participants considered the relief in acrylic more cognizable than on swell paper. In relation to people with normal color vision, the results are in accordance with 
the conclusions of Silveira (2011), because color perception can be similar for some normally sighted people and different for others. The use of the See Color code associated with the graphic variable Color can be an alternative for users to name the colors contained on maps. In this research, the See Color code showed the potential to provide spatial knowledge as a graphic language through colors on colored maps for the Adventitiously blind and for normally sighted participants based on their perception of colors and tactile color codes, as an alternative to maps that integrate the principle of universal design. However, in this experiment there was no equity in obtaining spatial knowledge by congenital blind through the subjective meaning of colors related to the theme average temperature, without the use of the map legend. Thus, future experiments are suggested to investigate how blind users could relate colors to spatial phenomena from their perception, before starting tasks with tactile maps and integrate the map legend. In this context, it is important to include the perception of color-blind and low-vision people and expand the participation of congenitally and adventitiously blind people for more statistically significant analysis.

\section{ACKNOWLEDGMENTS}

The authors would like to thank the Graduate Program in Geodesic Sciences, the Graduate Program in Cartographic Engineering, the National Council for Scientific and Technological Development (CNPq) for promoting Doctorate researches no 158303/2018-0, no 142253/2020-0 and Research Productivity Scholarship no 310312/20175, the ICB and the State School Papa João Paulo I for their support, and finally, all blind and visually impaired people and all students who participated in this study.

\section{AUTHORS' CONTRIBUTION}

The authors Niédja Sodré de Araújo, Fabrício Rosa Amorim and Amanda Pereira Antunes participated in the conceptualization and preparation of the text, as well as in the visualization and representation of the cartographic theme. Sandra Regina Marchi provided pedagogical material and technical drawings related to See Color code. Marcio Augusto Reolon Schmidt, Andrea Faria Andrade and Luciene Stamato Delazari worked on the conceptualization and development of the methodology, data curation, recommendation of formal techniques for analyzing the results and systematizing the experiment and also to the critical review of the text during pre-publication and to the editing of the manuscript.

\section{REFERENCES}

Almeida, R. A. 2011. A cartografia tátil na USP: duas décadas de pesquisa e ensino. In: FREITAS, M.I.C.(Ed.); VENTORINI, S.H (Ed). Cartografia tátil: orientação e mobilidade às pessoas com deficiência visual. Jundiaí: Paco Editorial, pp. 138-167.

Araújo, N. S. Amorim, F. R. Marchi, S. R. Andrade, A. F. Delazari, L. S. Schmidt, M. A. R. 2020. Avaliação do Sistema de Código de Cores "See Color"em Mapa Tátil. Uberlândia, Revista Brasileira de Cartografia, v. 72, n. 1, pp. 34-48. DOI http://dx.doi.org/10.14393/rbcv72n1-51660

Araújo, N. S. Fernandes, V. O. Alixandrini JR, M. J. 2019. Interpretação de Pessoas Cegas Sobre Símbolos 3D em Mapa Tátil de Ambiente Indoor. Revista Cartográfica, Buenos Aires, v. 99, pp. 95-105, DOI. 10.35424/rcarto.v0i99.422.

Bem, G. M. 2016. Parâmetros de fabricação de símbolos para mapas táteis arquitetônicos. Dissertação (Mestrado em Arquitetura e Urbanismo) - Programa de Pós-Graduação em Arquitetura e Urbanismo, Universidade Federal de Santa Catarina, Florianópolis. 
Bernardi, N. 2007. A aplicação do conceito do desenho universal no ensino de arquitetura: o uso de mapa tátil como leitura de projeto. Tese (Doutorado em Engenharia Civil) - Faculdade de Engenharia Civil, Arquitetura e Urbanismo, Universidade Estadual de Campinas, São Paulo.

Bianchi, C. Ramos, K. Barbosa-Lima, M. C. 2016. Conhecer as cores sem nunca tê-las visto. Revista Ensaio, Belo Horizonte, v. 18, n.1, pp. 147-164, DOI. https://doi.org/10.1590/1983-21172016180108.

Brasil, 2015. Lei no13.146, de 6 de julho de 2015. Lei Brasileira de Inclusão da Pessoa com Deficiência (Estatuto da Pessoa com Deficiência). [online] Available at: <http://www.planalto.gov.br/ccivil_03/_ato2015-2018/2015/lei/ 113146.htm> [Accessed 19 maio 2020].

Brazilian Ophthalmology Council, 2019. As condições de Saúde Ocular no Brasil. [pdf] Available at: <http://www. cbo.com.br/novo/publicacoes/condicoes_saude_ocular_brasil2019.pdf>. [Accessed 20 fevereiro 2019].

Dent, B. D. Torguson, J.S. Hodler, T. W. 2009. Cartography: Thematic Map Design. Dubuque: Brown Publishing Company. Jehoel, S. 2007. A series of psychological studies on the design of tactile maps. These. University of Surrey, Guilford.

Kitchin, R. M. Jacobson, D. R. 1997. Techniques to Collect and Analyze the Cognitive Map Knowledge of Persons with Visual Impairment or Blindness: Issues of Validity, Journal of Visual Impairment \& Blindness, July-August, pp.360-376.

Koch, W. G. 2012. State of the Art of Tactile Maps for Visually Impaired People. In: M. Buchroithner (Ed.). True-3D in Cartography: Autostereoscopic and Solid Visualisation of Geodata, Lecture Notes in Geoinformation and Cartography. Germany: Springer, pp. 137-149. DOI 10.1007/978-3-642-12272-9_9

Marchi, S. R. 2019. Design Universal de Código de Cores Tátil: Contribuição de Acessibilidade para Pessoas com Deficiência Visual. Tese (Doutorado em Engenharia Mecânica) - Programa de Pós-Graduação em Engenharia Mecânica, Universidade Federal do Paraná, Curitiba.

Ministry of Education, 2017. Base Nacional Comum Curricular. [pdf] Brasília. Available at: <http://basenacionalcomum. mec.gov.br/images/BNCC_El_EF_110518_versaofinal_site.pdf> [Accessed 20 fevereiro 2019].

Neiva, M. 2016. ColorADD. Color identification system for colorblind people. Lights On: Cultural Heritage and Museums!. Porto: LabCR FLUP, pp.34-43. DOI: 10.1007/978-3-662-53924-8_27

Nielsen, J. Landauer, T. K. 1993. A mathematical model of the finding of usability problems. Proceedings of ACM Interchi'93 Conference. Amsterdam: ACM Digital Library, pp. 206-213.

Nogueira, R. E. 2008. Cartografia Tátil: mapas para deficientes visuais. Portal da Cartografia, Londrina, v. 1, n. 1, pp. 35-58.

Nunes, S. S. Lomonaco, J. F. B. 2008. Desenvolvimento de conceitos em cegos congênitos: caminhos de aquisição do conhecimento. Revista Semestral da Associação Brasileira de Psicologia Escolar e Educacional, Campinas, v. 12, n. 1, pp.119-138. DOI. https://doi.org/10.1590/S1413-85572008000100009

Oliveira, J. V. G. 1988. Arte e visualidade: A questão da cegueira. Revista Benjamin Constant, v. 1, pp.7-10.

Pedrosa, I. 2010. Da cor à cor inexistente. Rio de janeiro: Senac Nacional.

Pugliesi, E. A. Decanini, M. M. S. 2011. Cartographic Design of In-Car Route Guidance for Color-Blind Users. International Cartographic Conference, Paris.

Ribeiro, G. Y. A. 2019. Aplicação do Código See Color em Imagens: Um Estudo de Caso. Dissertação (Mestrado em Design) - Programa de Pós-Graduação em Design, Universidade Federal do Paraná, Curitiba.

Silveira, L. M. 2011. Introdução à Teoria da Cor. Curitiba: UTFPR.

Štěrba, Z. Šašinka, Č. Stachoň, Z. Štampach, R. Morong, K. 2015. Selected Issues of Experimental Testing in Cartography. Brno: Masaryk University. DOI: 10.5817/CZ.MUNI.M210-7893-2015

Vasconcellos, R. 1993. Representing the geographical space for visually handicapped students: a case study on map use. 16th International Cartographic Conference Proceedings. Germany: Köln, pp. 993-1004. 


\section{Erratum}

On all pages where it reads:

Boletim de Ciências Geodésicas, 27(1)

\section{Should read:}

Boletim de Ciências Geodésicas, 27(spe)

Bulletin of Geodetic Sciences, 27(spe): e2021009, 2021 